\title{
LIDAR STAND-ALONE RETRIEVAL OF ATMOSPHERIC AEROSOL MICROPHYSICAL PROPERTIES DURING SLOPE
}

\author{
Pablo Ortiz-Amezcua ${ }^{1,2 *}$, Stefanos Samaras ${ }^{3}$, Christine Böckmann ${ }^{3}$, Jose Antonio Benavent- \\ Oltra $^{1,2}$, Juan Luis Guerrero-Rascado ${ }^{1,2}$, Roberto Román ${ }^{1,2}$, Lucas Alados-Arboledas ${ }^{1,2}$ \\ ${ }^{1}$ Andalusian Institute for Earth System Research (IISTA-CEAMA), Granada, \\ Spain,*portizamezcua@ugr.es \\ ${ }^{2}$ Department of Applied Physics, University of Granada, Spain \\ ${ }^{3}$ Institute for Mathematics, University of Potsdam, Germany
}

\begin{abstract}
Two cases from SLOPE campaign at Granada are analyzed in terms of particle microphysical properties using novel software developed at Potsdam University. Multiwavelength Raman lidar measurements of particle extinction and backscatter coefficients as well as linear particle depolarization ratios are used as input for the software. The result of the retrieval is a 2dimensional particle volume distribution as a function of radius and aspect ratio, from which the particle microphysical properties are obtained.
\end{abstract}

\section{INTRODUCTION}

Aerosol particles play an essential role on atmosphere and climate, and it is thus important to have vertically resolved information about their microphysical properties. Multiwavelength Raman lidar measurements allow for stand-alone microphysical retrievals, i. e., the calculation of particle microphysical properties using only Raman lidar data and applying regularization methods [1].

Most of the regularization methods use Mie theory to model aerosol particles as an ensemble of spheres, what usually provides fairly good results for small particles like biomass burning particles. However, using depolarization measurements makes possible to generalize the models to account for spheroidal particles and therefore, the retrievals include also information about the particle shape.

In this work, new software developed at the University of Potsdam [2] using a 2-dimensional approach is tested applying it to measurement cases from ACTRIS-2 experimental campaign SLOPE (Sierra Nevada Lidar AerOsol Profiling Experiment). That campaign was carried out in
Granada from May to August 2016, and was designed for gathering data useful for testing the retrieval schemes through inversion of remote sensing observations. It combined active and passive remote sensing together with in-situ measurements at several levels in the northern slope of Sierra Nevada mountain range.

\section{METHODOLOGY}

The present study has been carried out using data corresponding to measurements taken at the Andalusian Institute for Earth System Research (IISTA-CEAMA) in Granada $\left(37.16^{\circ} \mathrm{N}, 3.61^{\circ} \mathrm{W}\right.$, $680 \mathrm{~m}$ a.s.1.). This is a medium-size city in Southeastern Spain, located in a natural basin delimited by mountains reaching $3000 \mathrm{~m}$ a.s.l.; the air masses are mainly coming from the Atlantic Ocean, Europe, North Africa and the Mediterranean Basin [3]. The station is included in several research networks like EARLINET (European Aerosol Research Lidar Network) [4], and AERONET (Aerosol Robotic Network) [5].

The vertical profiles of particle optical properties were obtained using signals from the multiwavelength Raman lidar system MULHACEN (LR331D400, Raymetrics Inc.), configured in a monostatic biaxial alignment pointing vertically to the zenith. The light source is a pulsed Nd:YAG laser with emission at 355 , 532 and $1064 \mathrm{~nm}$ wavelength. The radiation is collected by a $40 \mathrm{~cm}$-diameter Cassegranian telescope, and it is then split into seven channels allowing the detection of elastic signals at 355 $\mathrm{nm}, 532 \mathrm{~nm}$ (in parallel and perpendicular polarizations) and $1064 \mathrm{~nm}$ and three Raman channels at 387 and $607 \mathrm{~nm}$ (nitrogen Raman shifted signal from 355 and $532 \mathrm{~nm}$, respectively) and $408 \mathrm{~nm}$ (water vapor Raman shifted signal 
from $355 \mathrm{~nm}$ ). This instrument has an overlap limitation due to its intrinsic setup, but it will not be taken into account in this work, since our study focuses in heights above $2 \mathrm{~km}$ a.s.l. [6]. The vertical profiles of particle backscatter $(\beta)$ and extinction $(\alpha)$ coefficients were retrieved from night-time lidar signals using the Raman algorithm [7]. The ratio between the perpendicular and parallel components of the particle backscatter coefficient at $532 \mathrm{~nm}$, known as linear particle depolarization ratio $\left(\delta_{P}\right)$ was also obtained following the calculation and calibration methods described in [8].

The set of $3 \beta$ (at 355, 532 and $1064 \mathrm{~nm}$ ), $2 \alpha$ (at 355 and $532 \mathrm{~nm}$ ) and $1 \delta_{P}$ (at $532 \mathrm{~nm}$ ) was employed as input for the regularization software to obtain particle microphysical properties. This software [2] is based on a generalization of Mie model in two dimensions accounting for nonspherical particles. In this way, an ensemble of spheroids characterized by their volumeequivalent radius $(r)$ and aspect ratio $(a)$ is considered, and the aerosol volume "shape-size" distribution $v(r, a)$ is obtained by regularization [9, 10]. A precalculated database is used for the calculation of the kernel functions produced by Mieschka tool based on T-matrix method [11]. The best solution is chosen from a grid of wavelength-independent real (RRI) and imaginary (IRI) parts of refractive index by means of least residual error. The microphysical properties are then obtained from the retrieved distribution: volume concentration $\left(v_{c}\right)$, effective radius $\left(r_{e f f}\right)$, effective aspect ratio $\left(a_{\text {eff }}\right)$ and single scattering albedo $(S S A)$.

Columnar microphysical data retrieved from a CIMEL CE-138 sun-photometer, belonging to AERONET and collocated with the lidar system, were used to compare with the lidar stand-alone regularization results. The algorithm used by AERONET retrieves microphysical properties such as the particle size distribution, complex refractive index, and effective radius, from almucantar spectral sky radiance measurements performed by ground-based sun photometers [5].

\section{RESULTS}

Two measurement cases were picked from the database created during SLOPE. In order to assess the performance of the regularization algorithm in different scenarios, cases with different aerosol types were selected, namely an aged smoke plume probably mixed with local pollution on $18^{\text {th }}$ May, and a mineral dust event from Sahara desert on $9^{\text {th }}$ June. The analyses of the cases are presented separately in the following subsections.

\subsection{Case I: $\mathbf{1 8}^{\text {th }}$ May 2016}

Several aerosol plumes coming from North America (according to backward trajectories, not shown here) were detected in May 2016. Fire detection maps from satellite measurements indicated wide regions of active forest fires that seemed to be the source of the aerosol arriving to Granada.

In Fig. 1, optical profiles from Raman lidar measurements are depicted for the case on $18^{\text {th }}$ May 2016 at 22:00-22:30 UTC. Particle backscatter coefficients showed values up to 2 $(\mathrm{Mm} \cdot \mathrm{sr})^{-1}$ at $532 \mathrm{~nm}$ in an aerosol layer centered around $2.5 \mathrm{~km}$ a.s.1. Low $\delta_{P}$ at $532 \mathrm{~nm}$ (less than $8 \%$ ) and strong spectral dependence of $\beta$, with $\beta$ related Angström Exponents $\left(\mathrm{AE}_{\beta}\right)$ around 2 indicated that the measured plume contained smoke particles from the North American Forest Fires, and thus small spherical particles were expected [12].

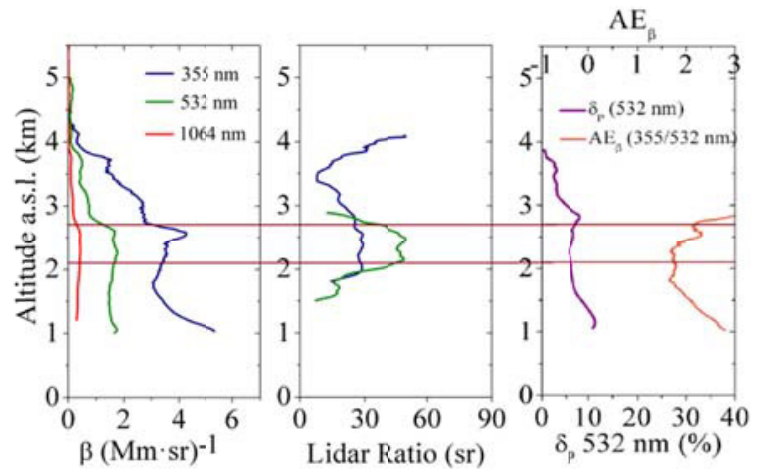

Figure 1: particle backscatter coefficient, lidar ratio, linear particle depolarization ratio and Angström exponent profiles for $18^{\text {th }}$ May 2016 at 22:00-22:30 UTC. Brown lines indicate the region selected for microphysical analysis

A region from 2.1 and $2.7 \mathrm{~km}$ a.s.l. was selected (Fig. 1) and its averaged optical properties were used as input for the regularization algorithm. The retrieved 2-dimensional particle volume distribution (not shown here) presented a single fine mode with microphysical properties included 
in Table 1, together with the results of the retrieval from the closest sun-photometer measurement. The results agree with typical values for aged smoke [12], and also include the information about shape: $a_{\text {eff }} 1.126$ and the mode width of the $a$ distribution, $a_{\text {width }} 0.048$ suggest spherical dominance and a hint of prolate particles.

Table 1: particle microphysical properties retrieved from lidar and from sun-photometer for $18^{\text {th }}$ May 2016

SSA is averaged for all wavelengths

\begin{tabular}{|l|l|l|}
\hline & $\begin{array}{l}\text { Lidar 22:00- } \\
\text { 22:30 UTC }\end{array}$ & $\begin{array}{l}\text { AERONET } \\
\mathbf{1 6 : 4 9} \text { UTC }\end{array}$ \\
\hline RRI & 1.42 & 1.511 \\
\hline IRI & 0.007 & $5 \cdot 10^{-5}$ \\
\hline $\mathbf{r}_{\text {eff }}(\boldsymbol{\mu m})$ & 0.26 & 0.295 \\
\hline $\mathbf{a}_{\text {eff }}$ & 1.126 & - \\
\hline $\mathbf{a}_{\text {width }}$ & 0.048 & - \\
\hline SSA & 0.96 & 0.992 \\
\hline
\end{tabular}

\subsection{Case II: $9^{\text {th }}$ June 2016}

The second case corresponds to a mineral dust plume coming from Sahara Desert, according to backward trajectories analysis (not shown here). The optical profiles for $9^{\text {th }}$ July 2016 at 01:0002:00 UTC (Fig. 2) confirm the decoupled strong dust layer between 2.5 and $5 \mathrm{~km}$ a.s.l., with $\beta$ more than $5(\mathrm{Mm} \cdot \mathrm{sr})^{-1}$ at $532 \mathrm{~nm}$. Particle lidar ratios around $50 \mathrm{sr}$ for both 355 and $532 \mathrm{~nm}$ channels, $\mathrm{AE}_{\beta}$ less than 0.5 and $\delta_{P}$ almost $30 \%$ reveal the presence of pure mineral dust particles in accordance to [13].

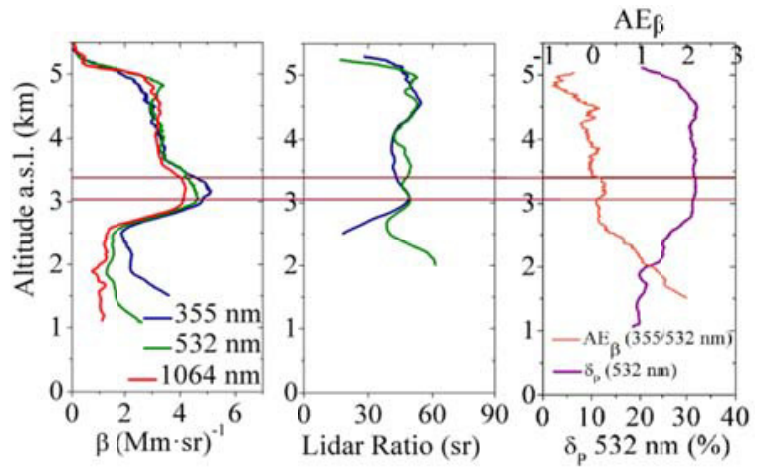

Figure 2: particle backscatter coefficient, lidar ratio, linear particle depolarization ratio and Angström exponent profiles for $9^{\text {th }}$ June 2016 at 01:00-02:00 UTC. Brown lines indicate the region selected for microphysical analysis
For the microphysical retrieval, the optical properties were averaged in the region from 3.05 to $3.4 \mathrm{~km}$ a.s.l. The results are shown in Table 2, compared with the AERONET retrievals some hours later. The results suggest large prolate spheroidal particles, with $r_{\text {eff }} 0.38 \mu \mathrm{m}$ and $a_{\text {eff }} 1.14$ (slightly higher than in Case I). There is a noteworthy similarity with the values from the sun-photometer retrieval, which can be an indication that the properties of the studied particles fairly represent the effective properties of the whole atmospheric column for this case. It has to be noted that the columnar $r_{\text {eff }}$ was calculated only from the part of the size distribution exactly coinciding with the range that can be analyzed with the lidar regularization algorithm, i. e., from 0 to $2.2 \mu \mathrm{m}$.

Table 2: particle microphysical properties retrieved from lidar and from sun-photometer for $9^{\text {th }}$ June 2016

SSA is averaged for all wavelengths

* $r_{\text {eff }}$ calculated from size distribution until $2.2 \mu \mathrm{m}$

\begin{tabular}{|l|l|l|}
\hline & $\begin{array}{l}\text { Lidar 01:00- } \\
\text { 02:00 UTC }\end{array}$ & $\begin{array}{l}\text { AERONET } \\
\text { 06:20 UTC }\end{array}$ \\
\hline RRI & 1.38 & 1.45 \\
\hline IRI & 0.003 & 0.002 \\
\hline $\mathbf{r}_{\text {eff }}(\boldsymbol{\mu m})$ & 0.38 & $0.4^{*}$ \\
\hline $\mathbf{a}_{\text {eff }}$ & 1.14 & - \\
\hline $\mathbf{a}_{\text {width }}$ & 0.047 & - \\
\hline SSA & 0.98 & 0.96 \\
\hline
\end{tabular}

\section{CONCLUSIONS}

This study presents the microphysical analysis of two different aerosol plumes measured with Raman lidar during the experimental campaign SLOPE at Granada in 2016.

The addition of depolarization measurements to the typical input setup for the regularization algorithm, making possible to use a more advanced 2-dimensional model for the particle volume distribution, was shown to be a successful option to obtain more information about size and shape of the analyzed particles. The effective radius was found $0.26 \mu \mathrm{m}$ for the aged smoke case, and $0.38 \mu \mathrm{m}$ for the mineral dust case. The effective aspect ratios indicated in both cases the predominance of prolate particles, although this feature was slightly more pronounced for the dust case. 


\section{ACKNOWLEDGEMENTS}

This work was supported by the Andalusia Regional Government through project P12-RNM2409, by the Spanish Ministry of Economy and Competitiveness through projects CGL201345410-R and CGL2016-81092-R, and grant FPU14/03684, and by the Erasmus+ Programme of the European Union. The financial support for EARLINET in the ACTRIS Research Infrastructure Project by the European Union's Horizon 2020 research and innovation program under grant agreement n. 654169 is gratefully acknowledged. FEDER program is acknowledged for the instrumentation used in this work. This work was also partially funded by the University of Granada through "Plan Propio. Programa 9. Convocatoria 2013".

\section{References}

[1] Müller, D., Böckmann, C., Kolgotin, A., Schneidenbach, L., Chemyakin, E., Rosemann, J., Znak, P., Romanov, A., 2016: Microphysical particle properties derived from inversion algorithms developed in the framework of EARLINET, Atmos. Meas. Tech. 9, 5007-5035.

[2] Samaras, S., Böckmann, C., Nicolae, D., 2016: Combined sphere-spheroid particle model for the retrieval of the microphysical aerosol parameters via regularized inversion of lidar data, EPJ Web of Conferences 119, 23022.

[3] Alados-Arboledas, L., Alcántara, A., Olmo, F. J., Martínez-Lozano, J. A., Estellés, V., Cachorro, V., Silva, A. M., Horvath, H., Gangl, M., Díaz, A., Pujadas, M., Lorente, J., Labajo, A., Sorribas, M., Pavese, G., 2008: Aerosol columnar properties retrieved from CIMEL radiometers during VELETA 2002, Atmos. Env. 42 (11), 2654-2667.

[4] Pappalardo, G., Amodeo, A., Apituley, A., Comeron, A., Freudenthaler, V., Linné, H., Ansmann, A., Bösenberg, J., D'Amico, G., Mattis, I., Mona, L., Wandinger, U., Amiridis, V., AladosArboledas, L., Nicolae, D., Wiegner, M., 2014: EARLINET: towards an advanced sustainable European aerosol lidar network, Atmos. Meas. Tech. 7, 2389-2409.

[5] Holben, B., N., Eck, T. F., Slutsker, I., Tanré, D., Buis, J. P., Setzer, A., Vermote, E., Reagan, J. A., Kaufman, Y. J., Nakajima, T., Lavenu, F., Jakowiak, I., Smirnov, A., 1998:
AERONET - A Federated Instrument Network and Data Archive for Aerosol Characterization, Remote Sens. Environ. 66(1), 1-16.

[6] Navas-Guzmán, F., Guerrero-Rascado, J. L., Aldados-Arboledas, L., 2011: Retrieval of the lidar overlap function using Raman signals, Óptica Pura y Aplicada 44(1), 71-75.

[7] Ansmann, A., Wandinger, U., Riebesell, M., Weitkamp, C., Michaelis, W., 1992: Independent measurement of extinction and backscatter profiles in cirrus clouds by using a combined Raman elastic-backscatter lidar, Appl. Opt. 31, 7113-7131.

[8] Bravo-Aranda, J. A., Navas-Guzmán, F., Guerrero-Rascado, J. L., Pérez-Ramírez, D., GranadosMuñoz, M. J., Alados-Arboledas, L., 2013: Analysis of lidar depolarization calibration procedure and application to the atmospheric aerosol characterization, Int. J. Remote Sens. 34, 3543-3560.

[9] Böckmann, C., 2001: Hybrid regularization method for the ill-posed inversion of multiwavelength lidar data in the retrieval of aerosol size distributions, Appl. Opt. 40(9), 1329-1342.

[10] Böckmann, C., Osterloh, L., 2014: RungeKutta type regularization method for inversion of spheroidal particle distribution from limited optical data, Inverse Probl. Sci. En. 22, 150165.

[11] Mishchenko, M., I., Travis, L., D., Mackowski, D. W., 1996: T-matrix computations of light scattering by nonspherical particles: A review, J. Quant. Spectrosc. Ra. 55(5), 535-575.

[12] Ortiz-Amezcua, P., Guerrero-Rascado, J. L., Granados-Muñoz, M. J., Benavent-Oltra, J. A., Böckmann, C., Samaras, S., Stachlewska, I. S., Janicka, Ł., Baars, H., Bohlmann, S., AladosArboledas, L., 2016: Microphysical characterization of long-range transported biomass burning particles from North America at three EARLINET stations, Atmos. Chem. Phys. Discuss., in review.

[13] Guerrero-Rascado, J. L., Ruiz, B., AladosArboledas, L., 2008: Multi-spectral Lidar characterization of the vertical structure of Saharan dust aerosol over Southern Spain, Atmos. Env. 22, 2668-2681. 